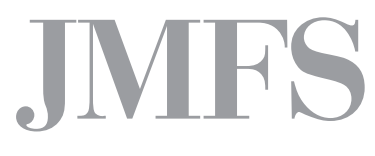

Journal of Management and Financial Sciences
Volume XII

Issue 39 (December 2019)

pp. 61-69

Warsaw School of Economics

Collegium of Management and Finance

Krzysztof Marecki, Maciej Wieloch

Collegium of Management and Finance

SGH Warsaw School of Economics

\title{
Dilemmas of the budgeting process
}

ABSTRACT

There is a common belief that planning is a key element of effective and efficient management of an enterprise. The budgeting process is a complex task, requiring making many decisions in various areas and taking into account variables dependent also on the specificity of the enterprise. Presenting both the expected benefits and the disadvantages and costs of a traditional budgeting process provides the basis for further considerations aimed at finding solutions that bring the expected benefits, while minimizing the disadvantages of the solution and adapting them to current expectations. There are voices that the traditional budgeting process should be completely abandoned. A postulate appears that budgeting in the form it is currently in use should be abolished. This may sound like a radical proposal, but it would only be the culmination of long-term efforts to transform organizations from centralized hierarchies into decentralized networks that allow for flexible adaptation to market conditions.

Keywords: budgeting, financial planning, beyond budgeting, budgeting process management, budgeting problems

JEL Classification Code: G30 


\section{Introduction}

There is a common belief that planning is a key element of effective and efficient management of an enterprise. The implementation of this belief reflects the adoption of business objectives included in financial plans as a result of the accepted assumptions, goals, decisions made and expectations. Therefore, it can be assumed that the financial planning of market economic entities is related to the process of making future decisions relating to the collection and processing of asset finance streams for its use in operating and investment activities [Marecki, 2003].

As a result of decisions related to financial plans, the budgeting process is introduced, which is the implementation of the plan at the operational, managerial and executive level. Turning to the definition of the budgeting process, it is a complex task that requires making many decisions in various areas and taking into account variables dependent also on the specificity of the enterprise [Naruć et al., 2008]. It is a dynamic process and a continuous long-term process. The preparation of the budget for the next year usually starts several months before the end of the current year. However, it depends on the complexity of the company's organizational structure and processes; the more decentralized management of a business entity, the earlier the budgeting process should start to take into account the time needed for information flow and budget negotiations. It can, therefore, be assumed that budgeting is the process of preparing, approving, implementing and controlling the budget [Szczypa, 2008, p. 125].

These basic definitions and long-term practice result in the fact that the budgeting process is a complex process requiring long-term planning. These elements cause more and more proposals to be put forward to change the traditional approach to budgeting for new concepts. The aim of the considerations carried out in this study will be an attempt to determine the balance of costs and benefits resulting from the budgeting process, supplemented with selected, exemplary concepts that allow achieving the objectives and expectations of the budgeting process, other than the one developed in the traditional approach to budgeting. These considerations will be followed by the discussion of new tools which can be adopted to the enterprise to bias the problems of the budgeting process.

\section{Benefits of the budgeting process}

The literature provides many universal tips on how to implement the budgeting process. In practice, when planning the entire process, one should take into account the specificity of the enterprise and keep in mind the basic factors affecting the shape of the budgeting system, which include [Kieras-Kogut, Krawczyk, 2003]:

- the purpose of using budgeting in an enterprise, resulting clearly from the implemented strategy; 
- the structure of responsibility centres in the enterprise, which determines the types and amount of operational budgets;

- information capabilities of the company, taking into account not only the availability of historical or future data, but also the cost of extensive records.

In order for the budgeting system to work properly and fulfill all its functions, its implementation should focus on meeting certain requirements. According to J. Komorowski, the most important requirements of the budgeting procedure include [Komorowski, 1997, pp. 27-28]:

- the work of the whole team;

- openness and partnership relations in solving problems;

- personal responsibility for the implementation of tasks;

- reliability and accuracy of estimates and financial plans;

- maintaining budgetary discipline in the area of budget allocation;

- compliance with the adopted schedules and deadlines;

- settlement of costs of tasks and work within the established limits, according to a previously prepared valuation and updated standards;

- recognition of the value of expenditures as actually incurred expenses, not registration costs;

- ensuring compliance of budgeting with the company's financial and accounting system;

- verification and improvement of the procedure, primarily avoiding the double structure of goals, double accounting and other irregularities.

Due to the necessity to take into account the specificity of budgeting, the goals set for the budgeting process will be different depending on the adopted and defined goals of an entity. Nevertheless, it is tempting to define the basic or key to the effectiveness and efficiency of the process, the goals and benefits to be achieved as a result of the process. Therefore, the budget is a motivating tool for the implementation of operational budgets and implementation of plans that have been set up. In large economic enterprises, budgeting helps managers of various levels to control and manage departments [Michałowska, 2014, pp. 409-417].

The expected benefits of the budgeting process were indicated by C. Drury, who distinguished the following reasons for which the budgets are prepared [Drury, 1997, p. 370]:

- support for planning the annual activity;

- coordination of activities of different parts of the organization and making sure that the activities of these parts are mutually harmonized;

- communicating intentions to managers of various responsibility centres;

- motivating managers to apply efforts to achieve goals set by the entire organization;

- business control;

- assessment of managers' work.

One should also indicate an important element of the budgeting process, namely the postulate, and in principle, the need to link the budgeting process with the long-term goals set in the company's strategy. The budgeting process in a narrow sense is focused on supporting operational activities, short-term. Obviously, there is a long-term, strategic budgeting process, but it is not usually so detailed in the sense of accuracy, time step or assumptions. Another 
postulate is the linking of operational, short-term budgets with the overriding objective of the company, hence the goal of increasing shareholder value.

\section{Problems related to the budgeting process}

Conducted research on the budgeting process has led to conclusions calling into question the effectiveness of processes in the face of rising costs and significant involvement of staff. Quite a common situation has been the situation of 'frustration' with a long-term increase in real operating costs (despite considerable pressure on margins), which questioned the efficiency of the budgeting process. As part of the analysis of the efficiency of the budgeting process in large enterprises, the following conclusions appeared [Schmidt, 1992, pp. 103-107]:

- budgeting consumed most of the year and involved several hundred employees and people;

- budgeting weakened the strategic solution; the staff was absorbed in the mechanics of budgeting, not strategic issues; senior management acknowledged that it cannot link budget expenditures to the strategic plan;

- participants usually focused on incremental costs, taking for granted costs included in the budget from the previous year;

- the budget structure did not reflect changes in the organization and processes of the enterprise, and people spent a lot of costs largely under someone else's control;

- budgets were not reliable.

In addition, the aforementioned problems also concerned issues such as 'playing out' the budgeting process, escalating conflicts in the enterprise structure, as well as stimulating information asymmetry in the organizational hierarchy.

From the point of view of the resources allocation of the enterprise, i.e. translating into the effectiveness of the entity's operation, depending on the enterprise, on average, about $5 \%$ of all full-time employees were allocated to budgeting activities.

An important element of the criticism or rather reported problems resulting from the implementation of the traditional budgeting process is the lowering of the propensity for innovative activities. The rigid fiscal framework and the need for precise planning stimulate conservatism and avoidance of risk in the activities of people involved in the process. This is a particularly undesirable aspect of budgeting in the context of a widespread belief in the need to develop or 'escape forward' in a changing environment and generate a competitive advantage based on the implementation of innovation [Marginson et al., 2006]. Interest and research on these issues are further stimulated by significant changes resulting from changes in organizational development. While many of these changes, such as the use of network structures, multifunctional project teams, matrix organizational models, the need for employee initiatives, the need for horizontal communication, aimed at supporting innovation and learning, cause significant difficulties in terms of control principles and processes, supervision and control on which traditional budgeting is based [Choudhury, 1986, pp. 189-198]. As a result of these 
problems, which have been noticed since the 1970s, but have recently intensified due to the above-mentioned elements, there is a progressive pressure on decentralization of management processes, with a particular emphasis on budgeting processes often indicated as the main 'culprits' of the budgeting process [Hope, Fraser, 2003b; Marginson, 1999].

It seems that the key aspects of the problems with the traditional approach are:

- lack of flexibility and ability to respond to changes in the turbulent environment. The rapidly changing economic environment requires an efficient organization response to external stimuli. Long planning periods mean that formally accepted as part of corporate approvals, budgets become obsolete and, as a result, fictitious at the time of approval. The variable environment means that it is impossible to precisely plan effects in a given time [Neelym, 2003, pp. 22-28];

- departing in many cases from building the value of enterprises based on multiplying the value of tangible fixed assets and shifting the burden of spending on spheres related to brand building, marketing, the know-how and competence of human teams. Capital expenditures required much more planning attention and to a large extent caused the need to control and coordinate both expenditure and expected benefits from the implementation of activities. Often these 'non-material' factors are the source of competitive advantage, the construction of the company's position and the source of its value. This is due to general economic trends, in this case primarily the ongoing servicisation of the economy and building a competitive advantage based primarily on marketing activities and not based on production potential [Kaplan, 2006];

- the life cycle of products has significantly shortened, resulting in the need to quickly adapt the organization to the new product portfolio and respond to all problems and risks related to the introduction of new products [Kaplan, 2006];

- evolutionary and revolutionary changes taking place in the organization and management processes, resulting primarily in the decentralization of management, including behavioural changes in the mentality of employees, especially the so-called Millennials, reluctant to operate under a rigid budgetary framework. They are happy, in turn, finding themselves in organizations that give apparent freedom. These changes result from a large need for trust, without which, it seems, it is difficult to gain trust. Managers also require flexibility from the budgeting process, which, at least in principle, should be linked to responsibility [Espinoza et al., 2010].

In addition, in the face of challenges caused by the above-mentioned factors from the environment, the budgeting process had other disadvantages, often of immanent nature, consisting in [Marginson et al., 2006]:

- the adopted budgets were not in line with the company's strategy;

- the involvement (costs incurred, allocated resources) of the organization was disproportionate to the benefits achieved;

- as part of the budgeting and optimization processes, the focus was on cost reduction rather than on activities that translated into an increase in the value of the enterprise. 
The presented defects and problems concerning the traditional budgeting process mean that from the point of view of enterprises it seems necessary to look for other tools supporting the effective functioning of enterprises.

\section{Review of alternatives to traditional budgeting concepts}

In the context under consideration, the key issue seems to be the possibility of creating a system that would allow for obtaining the expected benefits in a different way than using traditional methods of budgeting. There are, after all, a number of different tools supporting business management. The key ones are certainly IT systems that support management. They allow managers, often in real time, to obtain information about the managed entity. Collecting the right information in a well-ordered manner is the information base for making decisions, but also controlling the processes taking place in the enterprise. It seems that it is the loss of control and supervision that is the key reason for applying the traditional budgeting processes. Is it possible to use other tools that allow managers, on the one hand, to maintain supervision and control over the functioning of the entity, and on the other hand, to get rid of the problems and disadvantages of the traditional budgeting process? It seems that the key is to use the right tools and abandoning the budgeting system will improve the market situation of the company [Hope, Fraser, 2003a].

Other tools supporting or likely to replace the budgeting process in certain areas include a tool such as: Balanced Scorecard (BSC), Economic Value Added (EVA) or Activity-Based Costing $(\mathrm{ABC})$ or other systems of modern cost calculation. However, it is difficult to consider all these tools as substitutable for the traditional budgeting process. However, when used appropriately, they seem to be able to achieve, at least partially, expected potential benefits, determined by the requirements for budgeting. Therefore, it is difficult to talk about searching for a new tool, budgeting or, more broadly, tools that will replace one's traditional budgeting process in a one-to-one relationship. Therefore, an alternative system is being sought that allows for comprehensive and effective implementation of the objectives set before the traditional budgeting process.

The concept indicated as allowing to overcome some of the problems arising from budgeting is the concept of Beyond Budgeting (BB). This concept has emerged as the general name given to a set of different practices that are intended to replace the traditional budgeting process. Its basic feature is the need to move from a formalized model based on a centralized hierarchy to a model based on decentralized networks. Therefore, it is not a set of strictly defined techniques and tools, but rather a set of postulates and good practices that have so far proved effective in the experience of some entities [Hope, Fraser, 2003b]. The Beyond Budgeting concept can be called the concept of 'moving away from the budget', 'without budget' or 'off the budget'. 
The BB implementation should include the following six main principles:

- the organizational structure should have clearly defined areas of responsibility. Managers should have no doubts about their duties and their authority. The concept of the so-called internal market for business units;

- accepted management goals should be based on success and be related to shareholder value. Such targets may be based on key performance indicators (KPIs) and benchmarks in accordance with the principle of a balanced scorecard;

- managers should have considerable freedom in making decisions. The organizational structure should be relatively flat. Decisions of key teams at the top of the hierarchy should be responsible for decisions that generate value;

- the scope of responsibility of people in the top hierarchy should be connected with key functions such as relationships with customers and suppliers. The direct communication between all the parties involved should be facilitated;

- information support systems should be transparent and ethical. In this case, the ABC system may be useful.

Thus, Beyond Budgeting is a collection of certain recommendations, for which various tools or management concepts can be used. As part of the BB concepts implemented in various organizations, the following benefits were demonstrated for BB:

- faster reaction times. Working in a flexible organizational network and strategy as an 'adaptive process' allows managers to quickly respond to customer requests;

- increasing the level of innovation. Managers working in a system where performance is evaluated on the basis of the team's results encourage new solutions;

- lowering costs. In the context of BB, managers perceive costs through the prism of limited resources which must be effectively used, and as a 'right to spend' within the budget which must necessarily be used. BB is also likely to increase awareness of the objectives in which costs are incurred, and thus, the possibility of reducing costs;

- increasing the loyalty of customers and suppliers. The leading role of teams from the highest levels of hierarchy in dealing with customers and suppliers is likely to deepen these relationships.

The process of implementing BB assumptions should be gradual. Improving budgeting should include the implementation of the following elements [Neelym et al., 2003, pp. 22-28]:

- process based budgeting model (Activity Based Budgeting) - including planning and control based on the organization's process architecture, separation of activities and processes generating value for the organization;

- budgets from scratch - to avoid inefficiencies and inaccuracies with incremental budgets, in which last year's values are multiplied by a factor including, among others, inflation; expenses in the organization must be planned carefully every time;

- budgets that take into account key parameters from the point of view of the company's value - resulting from the belief that generating value for stakeholders/shareholders is the overriding objective of business management; 
- profit planning (the so-called 'profit circle') as a method for planning future cash flows and separating profit centres allows one to determine whether the organization generates adequate net cash flows, and whether financial resources are provided for investments;

- rolling budgeting - solves problems with delays in the budgeting process, is very well accepted in conditions of changes in the market environment, is a better solution than budgeting to a fixed point in time.

It seems that the process of moving away from traditional budgeting methods will be a slow process, particularly difficult in traditional manufacturing enterprises. The experience of more developed countries shows that, firstly, tools are implemented 'alongside' traditional budgeting (BSC, ABC, EVA and others) and only then gradually abandon the traditional budgeting process. It gives a possibility of supporting the organization with other tools and techniques as a kind of 'skeleton' that allows, at least to a minimum degree, for maintaining the required control. The resignation from the traditional budgeting process is also not complete, but rather concerns a comprehensive 'process': selected key values are still planned.

\section{Summary}

The presentation of both the expected benefits and the disadvantages and costs of traditional budgeting provides the basis for further considerations aimed at finding solutions that bring the expected benefits, while minimizing the disadvantages of the solution and adapting them to current expectations. There are voices in the literature that the traditional budgeting process should be completely abandoned [Hope, Fraser, 2003b]. A postulate appears that budgeting in the form it is currently in use should be abolished. This may sound like a radical proposal, but it would only be the culmination of long-term efforts to transform organizations from centralized hierarchies into decentralized networks that allow for flexible adaptation to market conditions. Entities have invested significant resources in IT networks, redesigning processes and a variety of management tools, including EVA (economic added value), balanced scorecards and activity-based costing. But the tools introduced do not bring the expected effect, because the budgeting process and the culture of 'command and control' that it supports remain dominant. Therefore, the conclusion is that using other management accounting tools it is possible to obtain better effects than it would result from the traditional budgeting process.

\section{References}

1. Choudhury, N. (1986). Responsibility accounting and controllability. Accounting and Business Research, Summer, pp. 189-198.

2. Drury, C. (1997). Rachunek kosztów. Warszawa: PWN. 
3. Espinoza, C., Ukleja, M., Rusch, C. (2010). Managing the Millennials - Discover the Core Competencies for Managing Today's. Hoboken, New Jersey:Wiley \& Sons, Inc.

4. Hope, J., Frazer, R. (2003a). Who needs budgets? Harvard Business Review, February, pp. 108-115.

5. Hope, J., Fraser, R. (2003b). Beyond Budgeting: How Managers Can Break Free from the Annual Performance Trap. Cambridge: Harvard Business Press.

6. Kaplan, R.S. (2006). The Competitive Advantage of Management Accounting. Journal of Management Accounting Research, Vol. 18.

7. Kieras-Kogut, O., Krawczyk, M. Budżetowanie - efektywna metoda zarządzania współczesnym przedsiębiorstwem. Retrieved from: http://controlling.info.pl/artykuly/budzetowanie-efektywnametoda-zarzadzania-wspolczesnym-przedsiebiorstwem,97.html

8. Komorowski, J. (1997). Budżetowanie jako metoda zarządzania przedsiębiorstwem. Warszawa: PWN.

9. Marecki, K. (2003). Rachunkowość menedżerska w gospodarce finansowej przedsiębiorstwa. Warszawa: Difin.

10. Marginson, D., Ogden, S., Frow, N. (2006). Budgeting and innovation. Complements or contradictions? Research Report, CIMA, London.

11. Marginson, D. (1999). Beyond the budgetary control system: towards a two-tiered process of management control. Management Accounting Research, No. 10, pp. 203-230.

12. Michałowska, K. (2014). Proces budżetowania i jego wpływ na sytuację finansową podmiotów gospodarczych. Zeszyty Naukowe Uniwersytetu Szczecińskiego, No. 803, Finanse, Rynki Finansowe, Ubezpieczenia, No. 66. Szczecin: Wydawnictwo Naukowe Uniwersytetu Szczecińskiego, pp. 409-417.

13. Naruć, W., Nowak, J., Wieloch, M. (2008). Operacyjne planowanie finansowe. Warszawa: Difin.

14. Neelym, A., Bourne, M., Adams, Ch. (2003). Better budgeting or beyond budgeting? Measuring Business Excellence, Vol. 7, Iss. 3, pp. 22-28.

15. Schmidt, J.A. (1992). Is it time to replace traditional budgeting? Journal of Accountancy, Vol. 174, No. 4, October, pp. 103-107.

16. Szczypa, P. (2008). Rachunkowość zarządcza. Warszawa: CeDeWu.pl. 